\title{
EMPLOYER BRANDING: EXPLORING ATTRACTIVENESS DIMENSIONS IN A MULTICULTURAL CONTEXT
}

\author{
Ludvík EGER ${ }^{1^{*}}$, Michal MIČÍK ${ }^{2}$, Mikuláš GANGUR ${ }^{3}$, Petr $\check{R}$ HOR $^{4}$ \\ ${ }^{1,2}$ Department of Marketing, Trade and Services, Faculty of Economics, \\ University of West Bohemia, Pilsen, Czech Republic \\ ${ }^{3}$ Department of Economics and Quantitative Methods, Faculty of Economics, \\ University of West Bohemia, Pilsen, Czech Republic \\ ${ }^{4}$ Department of Management, Faculty of Economics, University of South Bohemia, \\ Ceske Budejovice, Czech Republic
}

Received 31 October 2018; accepted 17 February 2019

\begin{abstract}
Attracting and retaining talented employees and gaining competitive advantage are important for organizations around the world. This study identifies and operationalizes the components of employer attractiveness from the perspective of potential employees. The study tests the employer attractiveness scale (EmpAt) by identifying the attractiveness dimensions of an employer brand among business students in the Czech Republic through exploratory factor analysis. We also search for similarities and differences among employer attractiveness dimensions through a cross-cultural comparison based on the results of previous studies. Businesses in today's globalised world need to attract potential employees globally and determine whether it would be better to use one corporate strategy or to customize their employer brand according to the cultural differences between countries. National, cultural, and gender differences are also investigated. The findings show factors that business students give the highest importance to when searching for an employer and that the factor's importance is influenced by gender. The findings of this study can be used to track the perceptions of current job applicants about the company and to appeal to "suitable target audiences" - potential employees. The results can be used by HR experts and practitioners in formulating and executing their communication and recruitment strategies.
\end{abstract}

Keywords: employer branding, organizational attractiveness, human resources, cultural difference, gender difference, recruitment strategy.

JEL Classification: M1, M3, D83.

\section{Introduction}

Employer branding is a growing field of study. The term "employer branding" has been defined in several ways. It has recently become a prominent topic in human resources management (HRM) research (Edwards, 2010; Martin, Gollan, \& Grigg, 2011). Organizations are

${ }^{\star}$ Corresponding author. E-mail: leger@kmo.zcu.cz

Copyright (C) 2019 The Author(s). Published by VGTU Press

This is an Open Access article distributed under the terms of the Creative Commons Attribution License (http://creativecommons. org/licenses/by/4.0/), which permits unrestricted use, distribution, and reproduction in any medium, provided the original author and source are credited. 
using employer branding to attract recruits and ensure that current employees are engaged in the culture and strategy of the organization. Developing a favourable employer brand requires managers and HR professionals to know which factors are important for attracting recruits to their organization (Eger, Mičík, \& Řehoř, 2018; Mičík \& Mičudová, 2018).

Attracting potential candidates is important to the recruitment process, which is key to organizations because human capital is crucial for competitive advantage (Brymer, Molloy, \& Gilbert, 2014). This study builds on research by Berthon, Ewing, and Hah (2005) by testing the employer attractiveness scale (EmpAt) and analysing the relationships between its dimensions for business students in the Czech Republic.

The main purpose of this study is to identify potential employees' perception of employers and their intentions to apply for a job, examine which of the attractiveness dimensions are significant to university students, and investigate if differences in the perceptions of employer attractiveness emerge according to gender.

Berthon et al. (2005) and followers of their work call for further research to develop and refine the EmpAt scale due to their claim that cross-cultural differences in employer attractiveness are likely to appear across cultures. We have responded to this call by examining if various aspects of employer branding and attractiveness have equal importance across different cultures. Our study tracks cross-cultural differences and identifies similarities and contrasts among the dimensions of attractiveness in employer branding. Additionally, the study identifies which employer attractiveness attributes have been prioritized by national groups examined by earlier studies.

The rest of this paper is organized as follows. First, a review of the literature on employer branding and organizational attractiveness is provided. Second, the dimensions of employer brand attractiveness are identified through exploratory factor analysis. Third, attractiveness dimensions based on gender are identified. Fourth, similarities and differences across aspects of employer branding attractiveness examined in the samples of several studies are identified and compared.

\section{Employer branding}

The term "employer brand" was introduced by Ambler and Barrow (1996) in their paper "The Employer Brand". The authors define "employer brand" as the package of functional, economical, and psychological benefits provided by employment and identified with the employer. Employer branding refers to an organization's reputation as an employer and its value proposition to its employees (Barrow \& Mosley, 2011). Botha, Bussin, and De Swardt (2011) note that the success of an employer brand is influenced by a number of factors, including target group needs, a differentiated employer value proposition (EVP), people strategy, brand consistency, employer brand communication, and the measurement of human resource (HR) employer branding efforts. The term "employer branding" suggests that an organization's characteristics as an employer are differentiated from those of its competitors. The term suggests that an organization benefits from employer branding when it is perceived as a great place to work by current employees. The employment brand highlights the unique aspects of the organization's employment offerings or environment (Backhaus \& Tikoo, 2004). 
Several studies have found that organizations with a good employer brand will attract more prospective employees (e.g. Cable \& Turban, 2003; Sivertzen, Nilsen, \& Olafsen, 2013; E. Alniacik, Ü. Alniacik, Erat, \& Akcin, 2014) and be better able to retain them (Gittell, Seidner, \& Wimbush, 2010). Having a favourable and distinctive employer brand is an important asset for organizations (Carpentier et al., 2017). However, little is known about how the perceptions that constitute this influential employer brand can be created, managed, or improved through recruitment communication and practices (Lievens \& Slaughter, 2016; Slaughter, Cable, \& Turban, 2014). It is posited that companies with strong employer brands can reduce the cost of employee acquisition, improve employee relations, and increase employee retention (Ritson, 2002; Berthon et al., 2005). In general, a positive employer brand image generates organizational attractiveness (Lievens, 2007), and attractiveness signifies congruency between the organization's values and goals and those of the prospective employees (Elegbe, 2018). Building a brand, improving public awareness, and increasing the loyalty of employees can influence recruitment of new qualified employees (Urbancova, Richter, Kucirkova, \& Jarkovska, 2017).

Berthon et al. (2005) go even further and suggest expanding the model from three dimensions to five: economic benefits stay in the group, while psychological benefits are broken down into interest value and social value, and functional benefits are broken down into development value and application value. Berthon et al. (2005) identify these dimensions from the perspective of potential employees. They have also developed a scale measurement of employer attractiveness (Roy, 2008).

These five dimensions reflect the extent to which an individual is attracted to an employer. The model with five core dimensions has been widely used in research on employer brand (Roy, 2008; Reis \& Braga, 2016; Sivertzen et al., 2013; Biswas \& Suar, 2013; P. Kaur, S. Sharma, J. Kaur, \& S. K. Sharma, 2015; Arachchige \& Robertson, 2011; Alniacik et al., 2014).

The role of employer branding is defined by Backhaus and Tikoo (2004) as a set of subjective beliefs regarding an exchange between an individual and an organization. The literature on employer branding aims to offer human resources (or brand) managers the analytical frameworks, empirical knowledge, and practical tools they require to establish and communicate employer brands successfully (Mölk \& Aurer, 2018). Also, the term reputation is often used to refer to the term employer brand. Some authors even define reputation as an integral part of employer branding (Verčič \& Ćorić, 2018). Employer branding is relevant in the context of employee engagement and retention, but our study focuses on the recruitment aspect only. Model that represent effect of branding on engagement and retention is shown in Figure 1.

As can be seen in Figure 1, employer value proposition and employer reputation are the main dimensions of employer attractiveness, and the main dimensions of employer brand loyalty are organizational culture and organizational identity. What is not evident in Figure 1 is the overlapping effect of dimensions; employer value proposition and employer reputation also play a role in employer brand loyalty, and organization identity and organizational culture also have an impact on employer attractiveness (eg. Sears, 2003; Knox \& Freeman, 2006; Lievens \& Highhouse, 2003; Backhaus \& Tikoo, 2004; Grigore \& Stancu, 2011). 


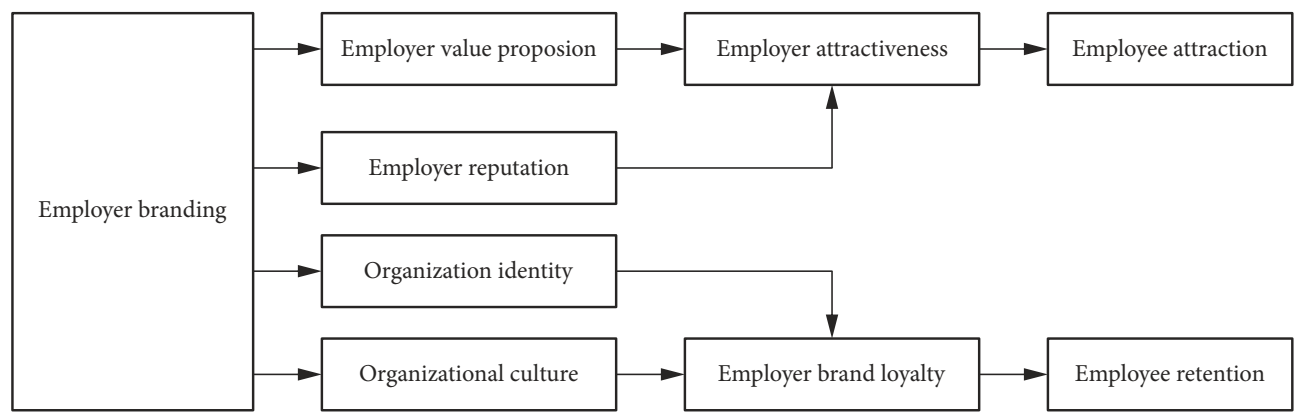

Figure 1. Effect of employer branding on retention and engagement of employees (source: own based on Backhaus \& Tikoo, 2004; Berthon et al., 2005)

\subsection{Employer branding and recruiting}

Saini, Rai, and Chaudhary (2014) and Elving, Westhoff, Meeusen, and Schoonderbeek (2013) agree that the employer brand is an efficient marketing tool that helps businesses represent themselves well to potential applicants. Many organizations strive to be perceived as an attractive and valued employer. Companies use numerous recruitment activities to let potential employees know about career opportunities and company characteristics (Perkins, Thomas, \& Taylor, 2000). Understanding the role of employer branding is key to the recruitment process that forms the candidate's experience and affects the employer's brand perception either positively or negatively.

Recruitment is defined as the process of sourcing (identifying a pool of potential applicants), attracting (generating and inducing interest of the potential targeted applicants), assessing (ascertaining work-related knowledge, skills, abilities, or other characteristics of an individual or group of individuals), and employing (engaging the services of or put a person to work) talent for an existing or new position within an organization (International Organization for Standardization, 2016). At present, when there is a shortage of skilled workers on the labor market, this process plays a very important role for all organizations.

Organizational reputation is significant factor in the recruitment process; it is formed through the company's image, which is in turn a reflection of the brand. Organizational reputation is defined as a set of characteristics that are socially constructed for an organization based on the organization's previous actions (Weigelt \& Camerer, 1988; Sivertzen et al., 2013), and image is defined as a set of beliefs, ideas, and impressions a person holds regarding an object (Kotler, 2003) - in our case, the employer. Organizations need to recognize the factors influencing their employer brands and their recruitment processes which form the candidates' perception of the employer brand and influences the candidates' decision to continue a relationship with the organization. Additionally, employer branding supports the relationship between employers and employees by providing competitive advantage with a positive impact on employee behaviour, such as retention (Miles \& Mangold, 2005; Ahmad \& Daud, 2016). This is particularly important in knowledge-based and service industries, where competent employees are often in short supply. Whereas traditional recruitment strategies are short-term and reflect current organizational needs, employer branding is a long-term 
strategy designed to maintain a steady flow of skilled employees (Srivastava \& Bhatnagar, 2010; Roy, 2008). Organizations are increasingly using social media for recruitment, however, little is known about its effects on potential applicants' perceptions of organizations as employers. Online social media represent a promising new tool for employer branding and recruitment (McFarland \& Ployhart, 2015; Nikolaou, 2014; Roth, Bobko, Van Iddekinge, \& Thatcher, 2016).

\subsection{Organizational attractiveness}

Companies have always cared about what their employees think and say about them (Dabirin, Kietzmann, \& Diba, 2017). Collective employee opinions not only shape the loyalty, engagement, and retention of existing workers but also influence how companies are seen publicly and how they are able to attract new talent. Companies can either benefit or suffer tremendously from the word-of-mouth their employees create and share (Kietzmann \& Canhoto, 2013). Most of the research has comprised in-depth theoretical discussions of the concept of being an attractive employer/organization or investigations into the main attributes of an attractive employer/organization (e.g. Lievens \& Highhouse, 2003; Backhaus \& Tikoo, 2004; Berthon et al., 2005; Joo \& McLean, 2006). Organizational attractiveness can be defined as the benefits potential employees anticipate from working for a specific organization (Berthon et al., 2005; Alniacik et al., 2014). From this point of view, it is important to understand what attracts a job seeker.

Organizational attractiveness is also considered the power that motivates an applicant to focus on an employer brand and encourages existing employees to stay (Bakanauskiene, Bendaravičienè, \& Barkauskè, 2017), as well as the degree to which potential and current employees perceive the organization as a good place to work (Jiang \& Iles, 2011). Ehrhart and Ziegert (2005) have defined organizational attraction as the process of getting candidates to view the organization as a positive place to work and have examined it from the applicant's perspective. Organizational attractiveness has been measured using the EmpAt scale (described above), developed by Berthon et al. (2005) and derived from Ambler and Barrow's (1996) dimensions of psychological, functional, and economic benefits.

Attractiveness and the prioritisation of attractiveness attributes may vary according to cultural and demographic characteristics (Alniacik et al., 2014; Reis \& Braga, 2016). Research shows that the personal characteristics of potential employees affect their perceptions of the attractiveness of companies (Albinger \& Freeman, 2000; Backhaus, Stone, \& Heiner, 2002). Moreover, female and male respondents may assess organizational attractiveness factors differently.

\section{Methodology}

In order to pursue the research objective - i. e. the identification of an employer attractiveness factors - we decided to adopt a quantitative research approach (Creswell, 2014). First, the study followed research by (Berthon et al., 2005) and tested the employer attractiveness scale (EmpAt) by identifying the attractiveness dimensions of an employer brand among business students in the Czech Republic through exploratory factor analysis (Mayers, Well, \& 
Lorch, 2010). Second, Kruskal-Wallis test (Kruskal \& Wallis, 1952) was employed to analyze differences in attractiveness dimensions and the nonparametric Mann-Whitney test (Mann \& Whitney, 1947) was used to identify the factor scores between females and males. Third, cross-cultural comparison based on the results of previous studies was conducted to identify the employer attractiveness attributes prioritized by national groups of respondents.

\subsection{Objectives and research questions}

The objectives of this study are threefold. The first objective is to identify the attractiveness dimensions of an employer brand among business students in the Czech Republic. We pose the following research question: What are potential employees' perceptions of employer attractiveness dimensions among business students in the Czech Republic?

The second objective is to examine whether statistically significant differences in attractiveness dimensions are observed based on gender. The relevant research question is as follows: Does the gender of the respondents (Czech business students) influence the level of importance they attribute to the dimensions of employer branding?

The third objective of the study is to identify similarities and differences between employer attractiveness dimensions through a cross-cultural comparison based on the results of previous studies. We pose the same research question as is posed in Alniacik et al. (2014): Are the aspects of employer branding and employer attractiveness being given equal importance in different cultures?

We meet the first objective through exploratory factor analysis using the principal components method followed by a rotation (McDonald, 1985). The number of original variables is reduced, and five key factors are identified. We meet the second objective by resting the following hypothesis: Aspects of attractiveness in employer branding are statistically significant based on gender. We meet the third objective by comparing similarities and differences between employer attractiveness factors and by testing the following hypothesis: The importance of attractiveness factors varies among the participants. A post hoc analysis of the test results is then conducted in order to compare importance levels between the paired dimensions.

\subsection{Sample and data collection}

A sample comprised of 281 final semester business students (209 females and 72 males) from two Economics faculties of two public universities in the Czech Republic was surveyed. The respondents ranged from 21 to 25 years of age. Their main field of study was business administration and management. Students from universities in Pilsen and České Budějovice well represent students from other economics faculties in Czech regions except Prague, where the situation in business activity, entrepreneurship, and in student employability is different.

Data were collected through a self-administered questionnaire that included demographic questions and the EmpAt scale developed by Berthon et al. (2005). Respondents were asked to indicate to what extent they considered the listed items important in choosing an employer. Responses were given on a five-point Likert scale ( 1 = "not at all important"; $5=$ “extremely important”). 


\subsection{Data analysis}

The data analysis is done as follows. First, confirmatory factor analysis was used to identify the attractiveness dimensions of an employer brand among business students in the Czech Republic. Second, descriptive statistics and the Kruskal-Wallis test was employed to examine whether statistically significant differences in attractiveness dimensions are observed based on gender. Third, the cross-cultural comparison of current research in the Czech Republic and of the results of previous studies was used to identify similarities and differences between employer attractiveness dimensions.

\subsection{Results}

Data were analysed in three stages. In the first, 25 variables on the attractiveness scale were factor analysed.

\section{Preliminary factor analysis: exploratory factor analysis}

First, the item-total correlation was calculated for every item. The value for all items was greater than 0.3 , and no items were eliminated. Then, the sampling adequacy of the items was examined via the Kaiser-Meyer-Olkin test (KMO). The value for the KMO statistic varied between 0 and 1 . A value close to 0 indicates that the sum of the partial correlations is large relative to the sum of the correlations, which would indicate an inappropriate factor analysis. Values between 0.7 and 0.8 are "good", values between 0.8 and 0.9 are "great", and values above 0.9 are "superb" (Kaiser, 1974).

KMO index is given by formula (1):

$$
\mathrm{KMO}=\frac{\sum_{i} \sum_{j \neq i}^{r_{i j}^{2}}}{\sum_{i} \sum_{j \neq i}^{r_{i j}^{2}+\sum_{i} \sum_{j \neq i} a_{i j}^{2}},}
$$

where $R=\left(r_{i j}\right)$ is correlation matrix of variables, $A=\left(a_{i j}\right)$ is partial correlation matrix of variables.

Partial correlation matrix is obtained from correlation matrix following formula (2):

$$
a_{i j}=\frac{v_{i j}}{\sqrt{v_{i i} \times v_{j j}}},
$$

where $V=\left(v_{i j}\right)=R^{-1}$ is inverse matrix of correlation matrix $\mathrm{R}$.

Our data produced a value of 0.91487 , indicating that the factor analysis was appropriate.

Also Bartlett's Test of Sphericity was used to determine the suitability and relevance of the data (Approx. Chi Square 3272.6683, df 300, p = 0.0000). Bartlett's Test of Sphericity showed significant value of 0.000 , indicating $\mathrm{p}<0.05$. Thus, it shows that the correlation between items is sufficient to run the factor analysis.

The Bartlett's test of sphericity statistic indicates to what extent we deviate from the reference situation $|R|=1$, i.e. identity correlation matrix. The test statistic $\mathrm{T}$ is given by formula (3):

$$
T=-\left(n-1-\frac{2 p+5}{6}\right) \times \ln |R|,
$$


where $n$ is number of observations, $p$ is number of variables (size of correlation matrix $\mathrm{R}$ ), $R=\left(r_{i j}\right)$ is correlation matrix of variables.

Subsequently, we used a principal component analysis with Raw Varimax rotation, and a factor extraction with respect to the MINEIGEN criterion (i.e. all factors with eigenvalues greater than 1) was employed. The five factors accounted for a cumulative $60.21 \%$ of the variation in the sample data. The initial eigenvalues and rotated component matrix are reported in Tables 1 and 2. Factor loadings $<0.45$ are suppressed, and the items are sorted by loading.

Table 1. Initial eigenvalues (source: own, 2018)

\begin{tabular}{|c|c|c|c|}
\hline Component & Total & \% variance & Cumulative \% \\
\hline 1 & 9.201 & 36.80 & 36.80 \\
\hline 2 & 1.83138 & 7.33 & 44.13 \\
\hline 3 & 1.63237 & 6.53 & 50.66 \\
\hline 4 & 1.36031 & 5.44 & 56.10 \\
\hline 5 & 1.02823 & 4.11 & 60.21 \\
\hline
\end{tabular}

The components partially correspond to the former Berthon factors of the EmpAt scale. Berthon's factors are ordered from factor 1 to factor 5, as follows: Interest value (IV), Social value (SV), Economic value (EV), Development value (DV), and Application value (AV). The results of our factor analysis grouped items in the following order (see Table 3): In our factor 1 , the Social value items dominate; Interest value items correspond fully with Berthon's factor 2; Application value items dominate in factor 3; our factor 4 consists of Economic value and Development value items (that is the reason for marking is as E-DV); finally, our factor 5 consists of the Development value and Application value items from Berthon's factors in the EmpAt scale (marked as D-AV). In both Berthon's study and ours, answers for the EmptAt scale items differ most for Interest value (IV) and Social value (SV). In our study, Social value (SV) and Interest value (IV) explain $44.13 \%$ of the variation. For further analysis, the factors will be labelled "factor 1 - SV", "factor 2 - IV", "factor 3 - AV", "factor 4 - E-DV", and "factor 5 - D-AV".

The following statistical analysis was performed on the scores for every factor and every participant. The score was computed as a linear combination of factor score coefficients (loadings $>0.45$ ) and source values of the items, and the score was then rescaled to the original scale. Table 2 shows the means and standard deviations of the scores for every factor.

Table 2. Means and standard deviation of factor scores (source: own, 2018)

\begin{tabular}{|l|c|c|c|c|c|}
\hline & SV & IV & AV & E-DV & D-AV \\
\hline Mean & 6,17 & 5.19 & 4.80 & 5.26 & 4.17 \\
\hline Median & 6.36 & 5.24 & 4.86 & 5.38 & 4.24 \\
\hline Standard deviation & 0.8107 & 0.7378 & 0.8189 & 0.7952 & 0.7846 \\
\hline
\end{tabular}


Table 3 shows the items used for each attractiveness dimension. Regarding the reliability of each item, although factory loadings of 0.70 or over are regarded as ideal, loadings between 0.50 and 0.70 are also acceptable; in such cases, the items may be retained (Hair, Ringle, \& Sarstedt, 2011; Reis \& Braga, 2016). Item Q24 was retained, even though it did not meet the reliability criterion, for the sake of the multicultural comparison conducted later, which is based on the factors of the original EmptAt.

Table 3. Factor analysis of items (source: own, 2018)

\begin{tabular}{|c|c|c|c|c|c|c|c|}
\hline $\begin{array}{l}\text { Berthon } \\
\text { items }\end{array}$ & $\begin{array}{c}\text { Factor } \\
1\end{array}$ & $\begin{array}{c}\text { Factor } \\
2\end{array}$ & $\begin{array}{c}\text { Factor } \\
3\end{array}$ & $\begin{array}{c}\text { Factor } \\
4\end{array}$ & $\begin{array}{c}\text { Factor } \\
5\end{array}$ & $\begin{array}{l}\text { Berthon } \\
\text { factors }\end{array}$ & Questions \\
\hline Q12 & 0.823 & & & & & SV & $\begin{array}{l}\text { Supportive and encouraging } \\
\text { colleagues }\end{array}$ \\
\hline Q10 & 0.820 & & & & & SV & $\begin{array}{l}\text { Having a good relationship with } \\
\text { your superiors }\end{array}$ \\
\hline Q11 & 0.802 & & & & & SV & $\begin{array}{l}\text { Having a good relationship with } \\
\text { your colleagues }\end{array}$ \\
\hline Q30 & 0.737 & & & & & SV & Happy work environment \\
\hline Q4 & 0.622 & & & & & SV & A fun working environment \\
\hline Q28 & 0.600 & & & & & EV & $\begin{array}{l}\text { Job security within the } \\
\text { organization }\end{array}$ \\
\hline Q26 & 0.578 & & & & & AV & Acceptance and belonging \\
\hline Q1 & 0.527 & & & & & DV & $\begin{array}{l}\text { Recognition/appreciation from } \\
\text { management }\end{array}$ \\
\hline Q18 & & 0.756 & & & & IV & $\begin{array}{l}\text { The organization produces } \\
\text { innovative products and services }\end{array}$ \\
\hline Q15 & & 0.714 & & & & IV & $\begin{array}{l}\text { Innovative employer; novel work } \\
\text { practices forward-thinking }\end{array}$ \\
\hline Q17 & & 0.664 & & & & IV & $\begin{array}{l}\text { The organization produces high- } \\
\text { quality products and services }\end{array}$ \\
\hline Q16 & & 0.543 & & & & IV & $\begin{array}{l}\text { The organization both values and } \\
\text { makes use of your creativity }\end{array}$ \\
\hline Q14 & & 0.505 & & & & IV & $\begin{array}{l}\text { Working in an exciting } \\
\text { environment }\end{array}$ \\
\hline Q25 & & & 0.737 & & & AV & $\begin{array}{l}\text { Opportunity to teach others what } \\
\text { you have learned }\end{array}$ \\
\hline Q27 & & & 0.643 & & & AV & $\begin{array}{l}\text { The organization is customer- } \\
\text { orientated }\end{array}$ \\
\hline Q29 & & & 0.514 & & & EV & $\begin{array}{l}\text { Hands-on inter-departmental } \\
\text { experience }\end{array}$ \\
\hline Q24 & & & 0.451 & & & AV & $\begin{array}{l}\text { Opportunity to apply what was } \\
\text { learned at a tertiary institution }\end{array}$ \\
\hline Q31 & & & & 0.748 & & EV & An above-average basic salary \\
\hline Q32 & & & & 0.717 & & EV & $\begin{array}{l}\text { An attractive overall } \\
\text { compensation package }\end{array}$ \\
\hline Q5 & & & & 0.629 & & DV & $\begin{array}{l}\text { A springboard for future } \\
\text { employment }\end{array}$ \\
\hline
\end{tabular}


End of Table 3

\begin{tabular}{|c|c|c|c|c|c|c|l|}
\hline $\begin{array}{c}\text { Berthon } \\
\text { items }\end{array}$ & $\begin{array}{c}\text { Factor } \\
1\end{array}$ & $\begin{array}{c}\text { Factor } \\
2\end{array}$ & $\begin{array}{c}\text { Factor } \\
3\end{array}$ & $\begin{array}{c}\text { Factor } \\
4\end{array}$ & $\begin{array}{c}\text { Factor } \\
5\end{array}$ & $\begin{array}{c}\text { Berthon } \\
\text { factors }\end{array}$ & \multicolumn{1}{|c|}{ Questions } \\
\hline Q8 & & & & 0.557 & & DV & $\begin{array}{l}\text { Gaming career-enhancing } \\
\text { experience }\end{array}$ \\
\hline Q19 & & & & 0.553 & & EV & $\begin{array}{l}\text { Good promotion opportunities } \\
\text { within the organization }\end{array}$ \\
\hline Q7 & & & & & 0.785 & DV & $\begin{array}{l}\text { Feeling more self-confident as a } \\
\text { result of working for a particular } \\
\text { org. }\end{array}$ \\
\hline Q6 & & & & & 0.666 & DV & $\begin{array}{l}\text { Feeling good about yourself as a } \\
\text { result of working for a particular } \\
\text { org. }\end{array}$ \\
\hline Q20 & & & & & 0.650 & AV & $\begin{array}{l}\text { Humanitarian organization, gives } \\
\text { back to society }\end{array}$ \\
\hline
\end{tabular}

Legend:

\begin{tabular}{|c|c|l|}
\hline & SV & Social value \\
\hline & EV & Economic value \\
\hline & IV & Interest value \\
\hline & AV & Application value \\
\hline & DV & Development value \\
\hline
\end{tabular}

Note: The "Berthon factors" column presents the original categorization of items according to the respective dimensions in Berthon et al. (2005), and Berthon's items and questions are numbered as in his original EmptAt scale.

The data used in our study, as in Berthon et al. (2005) and Arachchige \& Robertson (2011), were gathered from final-year business students through a self-completion questionnaire. Berthon et al. (2005) and Arachchige and Robertson (2011) also used the same 25item scale (EmpAt) and seven-point Likert scale (Arachchige and Robertson added seven additional factors but reported the alpha for the original scale).

The reliability of the employer attractiveness scale was examined based on inter-item consistency using Cronbach's alpha coefficient. The alpha for the original 25 items used in Berthon et al (2005) study was reported as 0.96. Arachchige and Robertson (2011) reported an alpha of 0.888 for the same items in their Sri Lankan study. In our study, the alpha of the scale was 0.905. Alniacik et al. (2014) applied the same 25 items but on a five-point Likert scale; the alpha was 0.91. Roy (2008) obtained 0.904 using a modified scale. It can thus be concluded that EmpAt is a reliable scale for the measurement of the attractiveness dimensions of an employer brand.

\section{Main analysis}

The next task is to compare the factor scores of the respondents and determine the importance of each factor. Based on the assumption that the importance of the factors will vary among the participants, we formulate the following hypothesis:

H1: The means (medians) of factor scores for every factor are different. 
First, the basic statistics were calculated. The means (medians) and standard deviation for every participant are presented in Table 2. The Kruskal-Wallis test was employed, and post-hoc analysis (multiple testing) was applied (Mayers et al., 2010).

In Kruskal-Wallis test all data are ranked from all groups together; i.e., rank the data from 1 to $\mathrm{N}$ ignoring group membership. Assign any tied values the average of the ranks they would have received had they not been tied. The test statistic $\mathrm{T}$ is given by (4):

$$
T=(N-1) \frac{\sum_{i=1}^{g} n_{i}\left(\overline{r_{i}}-\bar{r}\right)^{2}}{\sum_{i=1}^{g} \sum_{j=1}^{n_{i}}\left(r_{i j}-\bar{r}^{2}\right.},
$$

where $n_{i}$ is the number of observations in group $i, r_{i j}$ is the rank (among all observations) of observation $j$ from group $i, N$ is the total number of observations across all groups, $\bar{r}_{i} \sum_{j=1}^{n_{i}} \frac{r_{i j}}{n_{i}}$ is the average rank of all observations in group $\bar{r}=\frac{1}{2}(N+1)$ s the average of all the $r_{i j}$.

The $\mathrm{p}$-value is approximated by $\operatorname{Pr}\left(\mathrm{X}_{g-1}^{2} \geq T\right)$.

The p-value $(=0.0000)$ of the Kruskal-Wallis test supports hypothesis 1 . The five samples (one for every factor) are independent of each other, and normality was not proved in any sample. The p-values of the post-hoc analysis are reported in Table 4.

Table 4. Results of post-hoc analysis (p-values) (source: own, 2018)

\begin{tabular}{|c|c|c|c|c|c|}
\hline Factor(s) & SV & IV & AV & E-DV & D-AV \\
\hline SV & - & 0.000000 & 0.000000 & 0.000000 & 0.000000 \\
\hline IV & 0.000000 & - & 0.000003 & $\mathbf{1 . 0 0 0 0 0 0}$ & 0.000000 \\
\hline AV & 0.000000 & 0.000003 & - & 0.000000 & 0.000000 \\
\hline E-DV & 0.000000 & $\mathbf{1 . 0 0 0 0 0 0}$ & 0.000000 & - & 0.000000 \\
\hline D-AV & 0.000000 & 0.000000 & 0.000000 & 0.000000 & - \\
\hline
\end{tabular}

The p-values in the multiple testing show an exception to the result of the Kruskal-Wallis test. The difference between the score medians of IV and E-DV was not proved. The rest of the medians support the result of the previous Kruskal-Wallis test. The perceived importance of most factors differs for participants according to the mean values and medians in Table 2 . Therefore, we conclude that participants give the highest importance to Social value. Interest value and Economy-Development value are the second-most important attributes to the participants in our study. The difference in perception between them was not proved. These factors are followed by Application value, and the participants give the lowest importance to Development-Application value.

Based on the theory of organization attractiveness outlined above, the following analysis focuses on the influence of gender on the factors' importance. We investigate whether there is a statistically significant difference in perceptions of factors importance between men and women. We thus propose the following:

H2: The means (medians) of the factor scores differ between females and males. 
To test the hypothesis, the survey data were divided according to gender. The first sample comprised the female scores for particular factors, and the second one comprised the male scores for every factor. We performed five tests, one for each factor of the EmptAt scale. Due to the non-normality of all sample couples, the non-parametric Mann-Whitney test was used (Mayers et al., 2010).

In Mann-Whitney test $\mathrm{U}$ is given by

$$
U_{1}=R_{1}-\frac{n_{1}\left(n_{1}+1\right)}{2}
$$

where $n_{1}$ is the sample size for sample 1 , and $R_{1}$ is the sum of the ranks in sample 1 .

An equally valid formula for $U$ in sample 2 is

$$
U_{2}=R_{2}-\frac{n_{2}\left(n_{2}+1\right)}{2} .
$$

For large samples, $U=\min \left(U_{1}, U_{2}\right)$ is approximately normály distributed. Test statistic $T(X, Y)$ is calculated according to formula (7)

$$
T(X, Y)=\frac{U-\frac{n_{1} n_{2}}{2}}{\sqrt{\frac{n_{1} n_{2}\left(n_{1}+n_{2}+1\right)}{12}}} .
$$

All the basic parameters were calculated for every sample and factor. The results are reported in Table 5 .

Table 5. Gender sample parameters according to factors (source: own, 2018)

\begin{tabular}{|l|c|c|c|c|c|c|}
\hline Factor & Total & SV & IV & AV & E-DV & D-AV \\
\hline \multicolumn{7}{|c|}{ Mean/STD } \\
\hline F & $5.20 / 0.9958$ & $6.29 / 0.7372$ & $5.22 / 0.8788$ & $4.91 / 0.7675$ & $5.32 / 0.7678$ & $4.25 / 0.7632$ \\
\hline M & $4.88 / 1.0677$ & $5.81 / 0.9088$ & $5.10 / 0.6820$ & $4.48 / 0.8848$ & $5.07 / 0.8492$ & $3.95 / 0.8076$ \\
\hline \multicolumn{7}{|c|}{ Median } \\
\hline F & 5.23 & 6.47 & 5.24 & 4.92 & 5.41 & 4.33 \\
\hline M & 5.00 & 5.83 & 5.23 & 4.52 & 5.27 & 4.02 \\
\hline
\end{tabular}

Table 6 shows the results of the Mann-Whitney tests. The p-value $(=0.000003)$ indicates that there is no relationship between the observed variables. Therefore, hypothesis 2 was supported.

The data shown in Table 6 suggest that females attach higher importance to attractiveness factors than males do. Moreover, females consider more items to be important in most

Table 6. Results of Mann-Whitney test: comparison of gender scores according to factors (source: own, 2018)

\begin{tabular}{|c|c|c|c|c|c|c|}
\hline Factor & Total & SV & IV & AV & E-DV & D-AV \\
\hline p-value & $\mathbf{0 . 0 0 0 0 0 3}$ & $\mathbf{0 . 0 0 0 0 0 0}$ & 0.434727 & $\mathbf{0 . 0 0 0 2 3 2}$ & $\mathbf{0 . 0 1 6 2 5 5}$ & $\mathbf{0 , 0 0 2 0 4 3}$ \\
\hline
\end{tabular}


of the factors than males do. One exception is the Interest value items. In this case, the null hypothesis was not rejected ( $\mathrm{p}$-value $=0.434727$ ), and the test indicates a concordance in the importance of IV items between females and males. We can also observe some concordance in E-DV items, given the significance level of 0.01 .

\section{Cross-cultural comparison based on the results of previous studies}

Berthon et al. (2005) claim that cross-cultural differences in employer attractiveness are likely. The EmpAt cannot necessarily be extended cross-nationally without further psychometric testing. Berthon et al. (2005) identify the dimensions of employer attractiveness, which are likely to contribute to employer brand value. In Berthon et al. (2005), respondents were asked to rate the overall attractiveness of a well-known firm, in addition to the indicators in the EmpAt scale. A positive relationship was found between the five dimensions and overall attractiveness (Sivertzen et al., 2013). This part of our study examines which indicators of the EmpAt scale and which dimensions of attractiveness are important across cultural and national differences. To answer our third research question, we compared several studies that followed the survey conducted by Berthon et al. (2005). These surveys are described below.

The first objective of the survey conducted by Roy (2008) was focused on the attractiveness dimensions of an employer brand in an emerging market in India. The survey instrument was derived from the EmpAt scale developed by Berthon et al. (2005). Roy (2008) modified the scale and worked with seven factors (dimensions). Data were collected using self-administered questionnaires. Respondents (150 students of a management school) were asked to indicate the level of importance of each of the items in the scale using a five-point scale (Roy, 2008). The questioning was focused on the Indian companies that had been identified as the five best-managed in 2005. Therefore, this survey cannot be compared with those that accepted the original concept of Berthon et al. (2005).

Arachchige and Robertson (2011) focused on the factors that attracted Sri Lanka university graduates to potential employees. Their main objective was identifying the factors that were most important in determining the perceptions of job applicants. A sample of 221 final-year business students from Sri Lanka University was surveyed. Their research is based on the EmpAt scale developed by Berthon et al. (2005); the authors also compared the original 25 items (mean scores) between Sri Lankan and Australian students and used a seven-point Likert scale.

Sivertzen et al. (2013) asked Norwegian engineering students about three well-known Norwegian engineering firms in a web-based survey. Employer attractiveness was measured using the 25 indicators of the EmpAt scale developed by Berthon et al. (2005) on a sevenpoint Likert scale.

Alniacik et al. (2014) aimed to identify the perceptual differences in the importance levels of employer attractiveness dimensions between two cultures. The respondents consisted of 300 undergraduate and postgraduate students in Latvia and Turkey (half were employed and half unemployed). Data were collected by a self-administered questionnaire. The authors used 25 items of the EmpAt scale and a five point Likert scale.

The scale developed by Berthon et al. (2005) was also adopted in Reis and Braga's (2016) Brazilian study. The authors invited 3,000 professionals to fill in an online questionnaire. The 
return rate was $34 \%$ (937 responses from participants aged 21 to 65). They used a five-point Likert scale. Reis and Braga (2016) present the results of five dimensions of the EmpAt scale developed by Berthon et al. (2005) but only for 20 items. The authors adjusted the original items by deleting those with the lowest load factor values. The different sample (i.e. not only young people and university students) and reduced number of EmpAt items imposed limitations on their comparison.

We used the EmpAt scale developed by Berthon et al. (2005) to measure employer attractiveness. Data were collected via self-administered questionnaire using 25 items of the EmpAt scale and a seven-point Likert scale. The respondents were young university students (281 university business students from two faculties of Economics in the Czech Republic).

We divided the employer attributes in each survey into three quartiles, making the arrangement of the items independent from that of the original seven-point scale (Arachchige \& Robertson, 2011; Berthon et al., 2005; Sivertzen et al., 2013) and the five-point scale (Alniacik et al., 2014; Reis \& Braga, 2016). Differences were observed regarding how each group of respondents ranked the employer attributes.

Items from the third quartile show the most-preferred employer attributes, and items from the lowest quartile show the least-preferred. Outputs obtained this way can be used to draw comparisons with other international surveys and identify possible cultural and national differences. Several limitations are imposed, however. For example, Sivertzen et al. (2013) examined a selection of specific enterprises, and the output of Reis and Braga (2016) displayed only 20 items of the original 25, and the study's sample comprised not only business students but also professionals.

Table 7 presents the monitored items of the EmpAt scale, placed in order of the area's level of importance in terms of the possible application to employer brand development. Figure 2 graphically shows the differences between the mean scores of the employer attractiveness items according to the nationality of the respondents shown in Table 7.

The findings on the importance of the EmptAt scale items in each survey (see Table 7) must be compared with the findings from other surveys describing where the partial attributes lie and their significance. The following outlines several partial conclusions:

- The results show that, for Australian students (Berthon et al., 2005), the "happy work environment" item of Interest Value was more important than the other attributes (including Economic Value) for choosing an employer. Overall, however, the items of Interest Value were more important than the other attributes for Czech business students.

- Items of Social Value and Economic Value are among the most-preferred attributes in Berthon et al. (2005). There is only one item of Development Value ("Gaining experience that will help your career"). However, several other surveys show very different results (students in Sri Lanka and Turkey place development value items above all others and students from Latvia have two development value items among 6 most-preferred attributes).

- Four items of Development Value appear among the six most important values for business students in Sri Lanka (Arachchige \& Robertson, 2011). This represents an extreme outcome relative to other studies. 


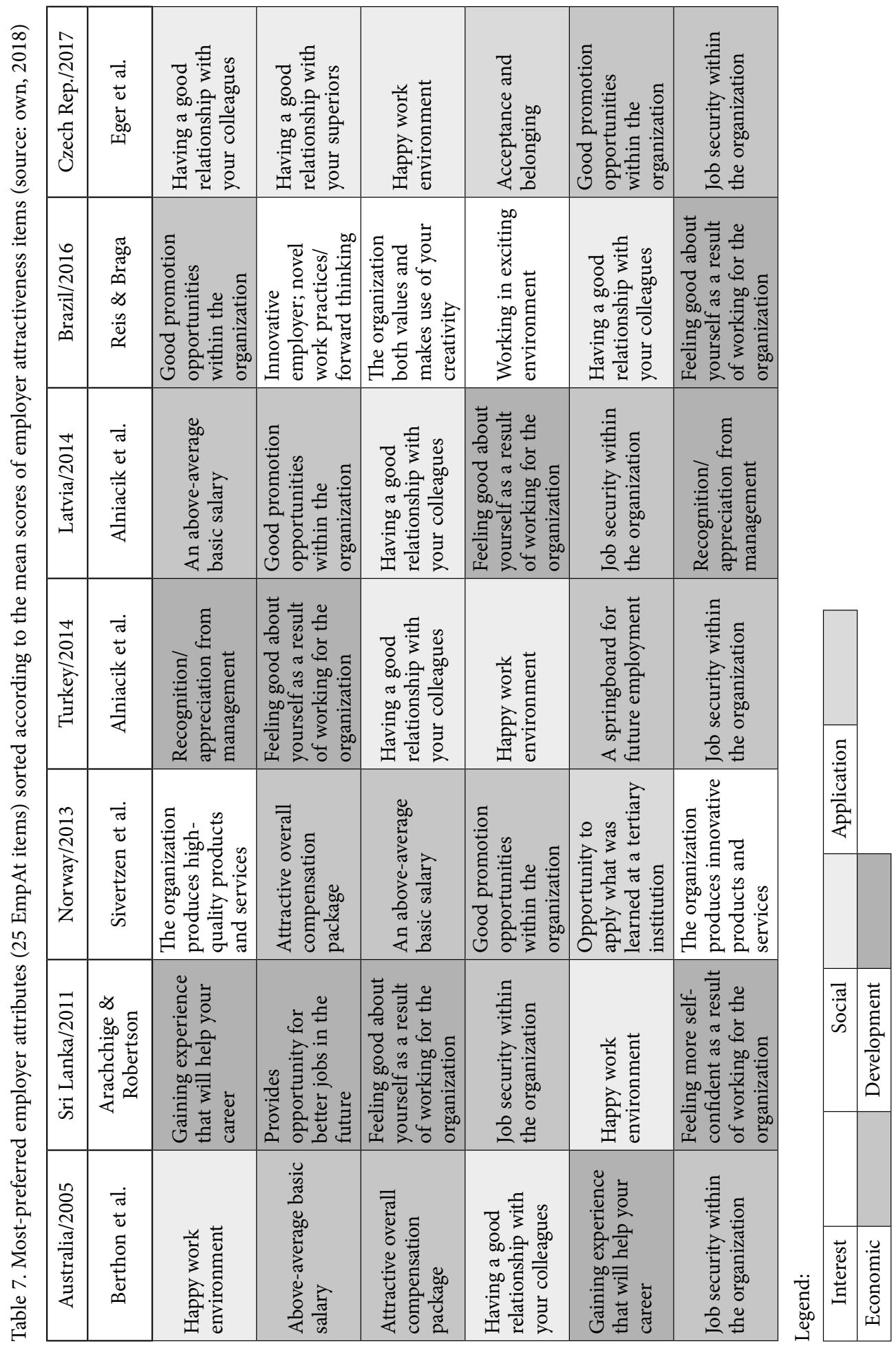


- Three items of Interest Value are among the most-preferred Employer Attributes in the survey from Brazil, and only the students from Norway (Sivertzen et al., 2013) also chose items of Interest Value (two) among the six most-preferred items.

- No Interest Value items are found in the sample of students from Turkey and Latvia (Alniacik et al., 2014).

- At least two out of the six most preferred attributes for the students from Australia, Norway, Turkey, and Latvia are Economic Value items. Only one item from Economic Value is among the most-preferred in the studies from Sri Lanka, Brazil, and the Czech Republic.

- The results show that the Application Value attributes appear in the survey outputs the least. This means that Application Value was the least-important attribute for all groups.

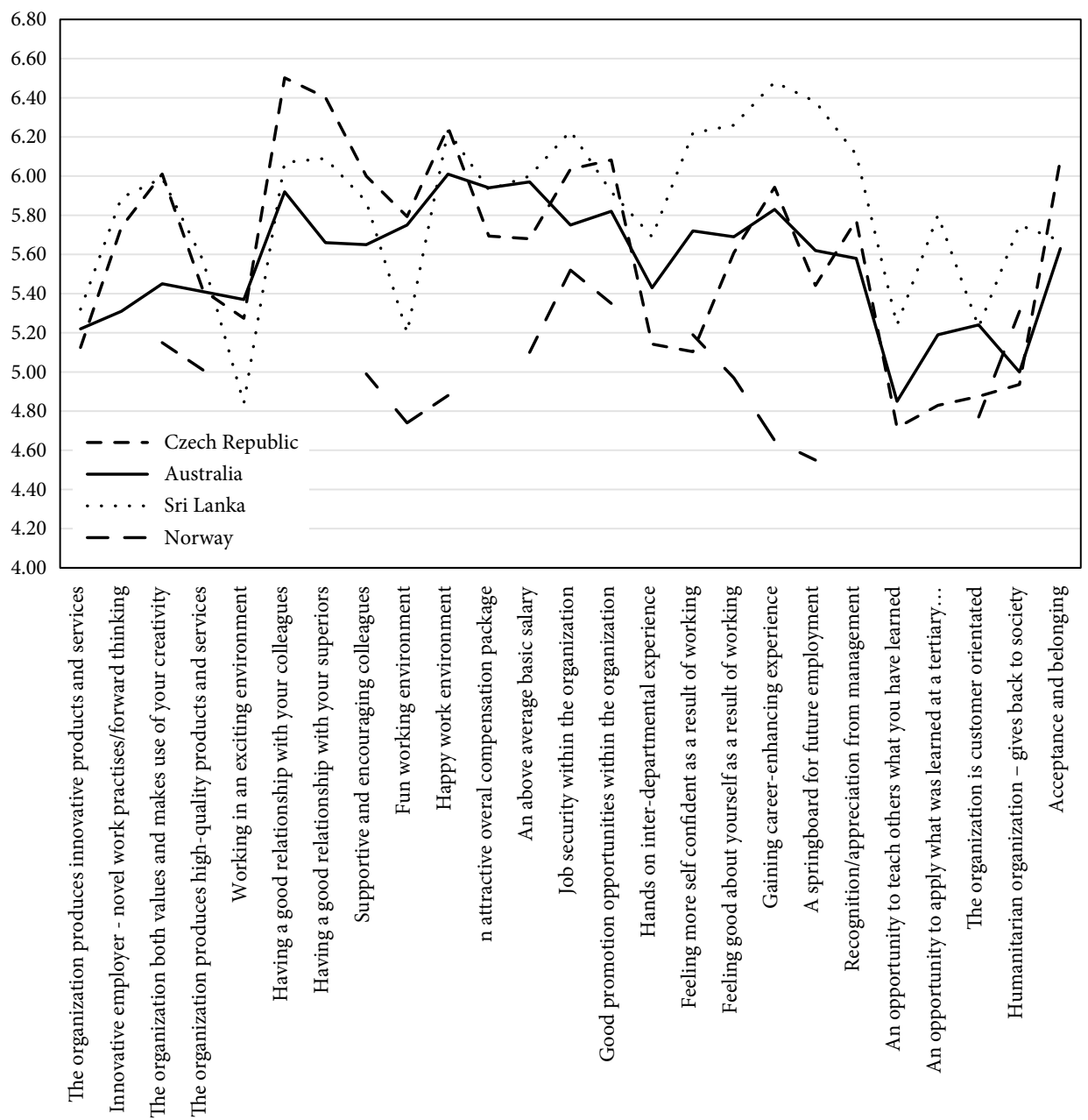

Figure 2. Differences in mean scores of employer attractiveness by nationality (source: own, 2018) Note: Research from Norway by Sivertzen et al. (2013) did not contain all the items from the study by Berthon et al. (2005). 
This comparison contributes to the research on employer branding by identifying the attributes of employer attractiveness that potential employees value most. Table 7 shows that Economic Value and Social Value attributes are important for most groups.

Interest Value is a primarily symbolic attribute (Lievens \& Highhouse, 2003) and concerns what an organization "is" (Srivastava \& Bhatnagar, 2010); it might thus be most important for recruiting professionals from a group of job applicants (Reis \& Braga, 2016). These factors are important for building a positive reputation, which will enhance intentions to apply for a job among potential employees, such as young people (Sivertzen et al., 2013).

Development Value is also an attractiveness factor that stands out. This attribute concerns whether an employer provides professional development and career growth opportunities. Development Value attributes were extremely important for students from Sri Lanka, Turkey, and Latvia. On the other hand, they were not among the preferred employer attributes for students from Norway or the Czech Republic.

Several partial conclusions can be drawn:

- The outputs of the six groups of respondents (see Table 8) show that, in the lower quartile, Application Value items appear most often. The Brazilian study is an exception; however, Reis and Braga (2016) narrowed the number of items to 20 from the original 25.

- Being innovative in terms of products and practices is of little importance for all groups of respondents, with the exception of those in Turkey.

- Brazilian respondents are again the exception, since two Economic Value items were among their least-preferred employer attributes. However, that study's respondents did not consist exclusively of young people and students.

This comparison aimed to identify the employer attractiveness attributes prioritized by national groups of respondents examined in prior research. The findings provide insights that should help firms design employer brand strategies targeting people from different cultures and demographic contexts.

\section{Conclusions}

\section{Discussion and implications}

In the first stage, this study identified the attractiveness factors in employer branding and examined which ones (i.e. values) were important to business students in the Czech Republic. The study found that Czech business students from selected universities attached the highest importance to Social Value. Interest Value and Economy-Development Value were the second-most important. These factors are important for building a positive firm reputation, which will enhance intentions to apply among potential employees. Organizations searching for talented young people should build their recruitment strategy based on such evaluations. Our findings can be used to track the perceptions of current job applicants about the company and to appeal to "suitable target audiences" - potential employees. The results can be used by marketing and HR experts and practitioners in formulating and executing their communication and recruitment strategies. 


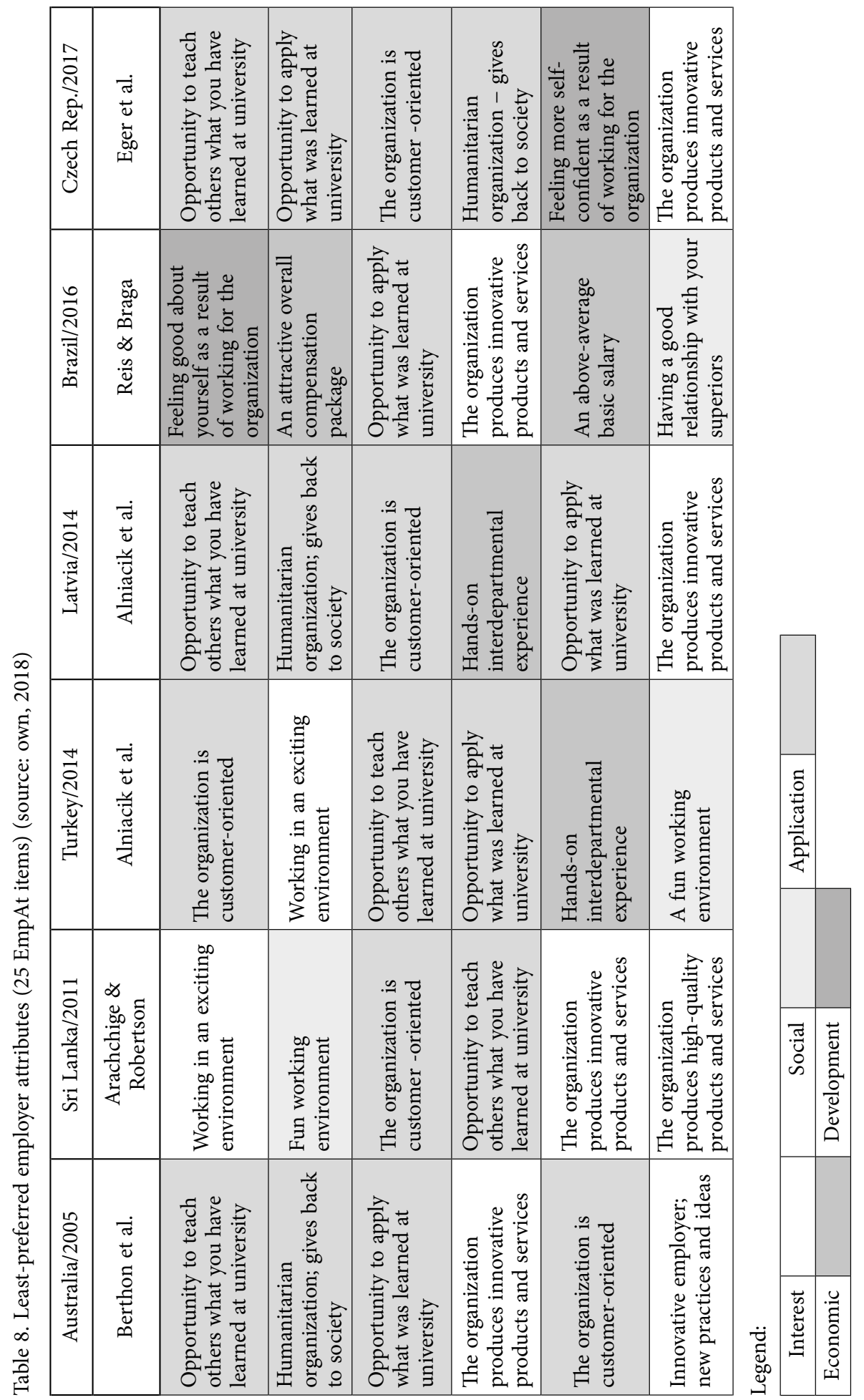


The second stage of analysis examined the influence of gender on factor importance levels. A comparison between males and females indicated several differences. The females considered significantly more factors to be important, including Social Value, Application Value, Economic-Development Value, and Development-Application Value. Only Interest Value had the same perceived importance for males and females. The other studies described above did not examine gender differences. Our findings thus call for further research on employer attractiveness items and gender differences.

The influence of cultural and economic factors on the business students was observed when comparing the prior results. This stage of our study clarifies which factors influence the employment preferences of job applicants (business students) from the international point of view, which is a fundamental prerequisite for both recruitment strategies and the development of an employer brand. The findings shown in Tables 7 and 8 address the assumption made by Berthon et al. (2005), indicating that cultural differences in an organization have important implications for international brand building.

Our examination of attractiveness attributes contributes to the literature by providing a different viewpoint on gender difference. The survey on attractiveness examines the prioritization of attributes that are usually offered by employers and shows which ones are preferred by business students. Managing these attributes, which represent the values of the employer brand, contributes to employer branding and effective recruitment. In relation to managers and HR-practitioners the results of the present research indicate several suggestions. First, employer branding campaigns and recruiting should respect differences in factors importance among target groups from different countries and coming from different cultures. Results underline that for Czech business students attach the highest importance to Social Values. A deeper understanding of what factors influence the preferences of job applicants is a fundamental and necessary prerequisite for a recruitment strategy and for the development of an employer brand.

\section{Limitations and issues for further research}

This study has several limitations. First, its first and second stages are focused on the Czech Republic and on a population with a high education level. Moreover, the survey does not examine the phenomenon of employer attractiveness over time.

Second, final-semester business students from two Economics faculties were chosen as respondents for this study, as they are attractive in the labour market. Using students as respondents has both advantages and disadvantages; for instance, it can reduce the findings' external validity and generalizability (Berthon et al., 2005; Sivertzen et al., 2013). The sample represents students of the faculties of economics from the regions in the Czech Republic except Prague, as mentioned above. Generalizing these findings to students from other study programs could be misleading. On the other hand, almost all other studies (e.g. Arachchige \& Robertson, 2011; Berthon et al., 2005; Sivertzen et al., 2013) have used the same kinds of participants (i.e. business students). Thus, our sample is homogenous and allows us to compare our results with those of the other studies. Such a comparison should assist in determining the most effective recruitment strategies for business students, a common recruitment target for organizations. The scope and depth of our discussion is compromised by being confined to the selected research surveys. 
Third, the fact that the survey is answered by using self-reports by the respondents may be a limitation. However, research follows previously conducted studies which allows an above made international comparison.

Employer branding has become a widespread and growing practice in several studies mentioned earlier (Ahmad \& Daud, 2016; Edwards, 2010; Reis \& Braga, 2016). Our findings point to several possible directions for future research. We suggest conducting surveys focused on employer attractiveness in other countries, cultures, and socioeconomic conditions. Organizations in our increasingly globalised economy need to understand the impact of different cultures on the perceptions of potential employees, especially with regard to talent management (Collings \& Mellahi, 2010; Egerová, Lančarič, Eger, \& Savov, 2015; Schuler, Jackson, \& Tarique, 2011). Moreover, future research should be focused not only on university students but also on other kinds of employees (e.g. Reis \& Braga, 2016). As our study shows, it is also important to examine the influence of gender on the levels of importance attributed to the dimensions of employer branding.

\section{Disclosure statement}

On behalf of all authors, the corresponding author states that there is no conflict of interest Specifically, there is no competing financial, professional, or personal interests from other parties.

\section{References}

Ahmad, A. D., \& Daud, S. (2016). Engaging people with employer branding. Procedia - Economics and Finance, 35, 690-698. https://doi.org/10.1016/S2212-5671(16)00086-1

Albinger, H. S., \& Freeman, S. J. (2000). Corporate social performance and attractiveness as an employer to different job seeking populations. Journal of Business Ethics, 28(3), 243-253.

https://doi.org/10.1023/A:1006289817941

Alniacik, E., Alniacik, Ü., Erat, S., \& Akcin, K. (2014). Attracting talented employees to the company: do we need different employer branding strategies in different cultures? Procedia - Social and Behavioral Sciences, 150, 336-334. https://doi:/10.1016/j.sbspro.2014.09.074

Ambler, T., \& Barrow, S. (1996). The employer brand. Journal of Brand Management, 4(3), 185-206. https://doi.org/10.1057/bm.1996.42

Arachchige, B., \& Robertson, A. (2011). Business students perceptions of a preferred employer: a study identifying determinats of employer branding. The UIP Journal of Brand Management, 3, 25-46.

Backhaus, K., Stone, B., \& Heiner, K. (2002). Exploring the relationship between corporate social performance and employer attractiveness. Business and Society, 41(3), 292-319. https://doi.org/10.1177/0007650302041003003

Backhaus, K., \& Tikoo, S. (2004). Conceptualizing and researching employer branding. Career Development International, 9(5), 501-517. https://doi.org/10.1108/13620430410550754

Bakanauskiene, I., Bendaravičienè, R., \& Barkauskè, L. (2017). Organizational attractiveness: An empirical study on employees attitudes in Lithuanian business sector. Problems and Perspectives in Management, 15(2), 4-18. https://doi.org/10.21511/ppm.15(2).2017.01

Barrow, S., \& Mosley, R. (2011). The employer brand: Bringing the best of brand management to people at work. Hoboken: John Wiley \& Sons. 
Berthon, P., Ewing, M., \& Hah, L. L. (2005). Captivating company: dimensions of attractiveness in employer branding. International Journal of Advertising, 24(2), 151-172. https://doi.org/10.1080/02650487.2005.11072912

Biswas, M., \& Suar, D. (2013). Which employees' values matter most in the creation of employer branding? Journal of Marketing Development and Competitiveness, 7(1), 93-102.

Botha, A., Bussin, M., \& De Swardt, L. (2011). An employer brand predictive model for talent attraction and retention. SA Journal of Human Resource Management, 9(1), 1-12. https://doi.org/10.4102/sajhrm.v9i1.388

Brymer, R. A., Molloy, J. C., \& Gilbert, B. A. (2014). Human capital pipelines competitive implications of repeated interorganizational hiring. Journal of Management, 40(2), 483-508. https://doi.org/10.1177/0149206313516797

Cable, D. M., \& Turban, D. B. (2003). The value of organizational reputation in the recruitment context: a brand-equity perspective. Journal of Applied Social Psychology, 33(11), 2244-2266.

https://doi.org/10.1111/j.1559-1816.2003.tb01883.x

Carpentier, M., Van Hoye, G., Stockman, S., Schollaert, E., Van Theemsche, B., \& Jacobs, G. (2017). Recruiting nurses through social media: Effects on employer brand and attractiveness. Journal of Advanced Nursing, 73(11), 2696-2708. https://doi.org/10.1111/jan.13336

Collings, D. G., \& Mellahi, K. (2010). Strategic talent management: A review and research agenda. Human Resource Management Review, 18(4), 304-313. https://doi.org/10.1016/j.hrmr.2009.04.001

Creswell, W. J. (2014). Research design. In Qualitative, quantitative, and mixed methods approaches. Thousand Oaks: SAGE.

Dabirin, A., Kietzmann, J., \& Diba, H. (2017). A great place to work? Understanding crowdsourced employer branding. Business Horizons, 60(2), 197-205. https://doi.org/10.1016/j.bushor.2016.11.005

Edwards, M. R. (2010). An integrative review of employer branding and OB theory. Personnel Review, 39(1), 5-23. https://doi.org/10.1108/00483481011012809

Eger, L., Mičík, M., \& Řehoř, P. (2018). Emloyer branding on social media and recruitment websites: Symbolic traits of an ideal employer. E+M. Ekonomie a Management, 21(1), 224-237. https://doi.org/10.15240/tul/001/2018-1-015

Egerová, D., Lančarič, D., Eger, L., \& Savov, R. (2015). Perspectives of talent management: Evidence from Czech and Slovak business organisations. E+M. Ekonomie a Management, 18(4), 108-120. https://doi.org/10.15240/tul/001/2015-4-008

Elegbe, J. A. (2018). Determinants of success of employer branding in a start-up firm in Nigeria. Thunderbird International Business Review, 60(3), 265-277. https://doi.org/10.1002/tie.21897

Elving, W. J. L., Westhoff, J. J. C., Meeusen, K., \& Schoonderbeek, J. W. (2013). The war for talent the relevance of employer branding in job advertisements for becoming an employer of choice. Journal of Brand Management, 20, 355-373. https://doi.org/10.1057/bm.2012.21

Ehrhart, K. H., \& Ziegert, J. C. (2005). Why are individuals attracted to organizations? Journal of Management, 31(6), 901-919. https://doi.org/10.1177/0149206305279759

International Organization for Standardization. (2016, September). Human resource management - guidelines on recruitment (ISO 30405:2016). Retrieved from https://www.iso.org/obp/ ui/\#iso:std:iso:30405:ed-1:v1:en

Gittell, J. H., Seidner, R., \& Wimbush, J. (2010). A relational model of how high-performance work systems work. Organization Science, 21(2), 490-506. https://doi.org/10.1287/orsc.1090.0446

Grigore, G. F., \& Stancu, A. (2011). The role of corporate social responsibility in building employer's brand. Transformations in Business \& Economics, 10(2), 741-753.

Hair, J., Ringle, C., \& Sarstedt, M. (2011). PLS-SEM: indeed a silver bullet. Journal of Marketing theory and Practise, 19(2), 139-152. https://doi.org/10.2753/MTP1069-6679190202 
Jiang, T., \& Iles, P. (2011). Employer-brand equity, organizational attractiveness and talent management in the Zhejiang private sector, China. Journal of Technology Management in China, 6(1), 97-110. https://doi.org/10.1108/17468771111105686

Joo, B. K., \& McLean, G. N. (2006). Best employer studies: a conceptual model from a literature review and a case study? Human Resource Development Review, 5(2), 228-257. https://doi.org/10.1177/1534484306287515

Kaiser, H. (1974). An index of factor simplicity. Psychometrika, 39, 31-36. https://doi.org/10.1007/BF02291575

Kaur, P., Sharma, S., Kaur, J., \& Sharma, S. K. (2015). Using social media for employer branding and talent management: an experiential study. The IUP Journal of Brand Management, 12(2), 7-20.

Kietzmann, J. H., \& Canhoto, A. (2013). Understanding and managing electronic word of mouth. Journal of Public Affairs, 13(2), 146-159. https://doi.org/10.1002/pa.1470

Knox, S., \& Freeman, C. (2006). Measuring and managing employer brand image in the service industry. Journal of Marketing Management, 22, 695-716. https://doi.org/10.1362/026725706778612103

Kotler, P. (2003). Marketing management. Upper Saddle River: Prentice Hall.

Kruskal, H. W., \& Wallis, W. A. (1952). Use of ranks in one-criterion variance analysis. Journal of the American Statistical Association, 47(260), 583-621. https://doi.org/10.1080/01621459.1952.10483441

Lievens, F. (2007). Employer branding in the Belgian army: The importance of instrumental and symbolic beliefs for potential applicants, actual applicants, and military employees. Human Resource Management, 46, 51-69. https://doi.org/10.1002/hrm.20145

Lievens, F., \& Highhouse, S. (2003). The relation of instrumental and symbolic attributes to a company's attractiveness as an employer. Personnel Psychology, 56(1), 75-102.

https://doi.org/10.1111/j.1744-6570.2003.tb00144.x

Lievens, F., \& Slaughter, J. E. (2016). Employer image and employer branding: What we know and what we need to know. Annual Review of Organizational Psychology and Organizational Behavior, 3, 407440. https://doi.org/10.1146/annurev-orgpsych-041015-062501

Mann, H. B., \& Whitney, D. R. (1947). On a test of whether one of two random variables is stochastically larger than the other. Annals of Mathematical Statistics, 18(1), 50-60. https://doi:10.1214/aoms/1177730491

Martin, G., Gollan, P. J., \& Grigg, K. (2011). Is there a bigger and better future for employer branding? Facing up to innovation, corporate reputations and wicked problems in SHRM. The International Journal of Human Resource Management, 22(17), 3618-3637. https://doi.org/10.1080/09585192.2011.560880

Mayers, J. L., Well, A. D., \& Lorch, Jr. R. F. (2010). Research design and statistical analysis. New York: Routledge.

McDonald, R. P. (1985). Factor analysis and related methods. East Sussex: Psychology Press.

McFarland, L. A., \& Ployhart, R. E. (2015). Social media: A contextual framework to guide research and practice. Journal of Applied Psychology, 100(6), 1653-1677. https://doi.org/10.1037/a0039244

Mičík, M., \& Mičudová, K. (2018). Employer brand building: using social media and career websites to attract generation Y. Economics \& Sociology, 11(3), 171-189.

https://doi.org/10.14254/2071-789X.2018/11-3/11

Miles, S. J., \& Mangold, W. G. (2005). Positioning southwest airlines through employee branding. Business Horizons, 48, 535-545. https://doi.org/10.1016/j.bushor.2005.04.010

Mölk, A., \& Aurer, M. (2018). Designing brands and managing organizational politics: A qualitative case study of employer brand creation. European Management Journal, 36(4), 485-496. https://doi.org/10.1016/j.emj.2017.07.005 
Nikolaou, I. (2014). Social networking web sites in job search and employee recruitment. International Journal of Selection and Assessment, 22(2), 179-189. https://doi.org/10.1111/ijsa.12067

Perkins, L. A., Thomas, K. M., \& Taylor, G. A. (2000). Advertising and recruitment: Marketing to minorities. Psychology \& Marketing, 17(3), 235-255.

Reis, G. G., \& Braga, M. B. (2016). Employer attractiveness from a generational perspective: Implications for employer branding. Revista de Administração, 51, 103-116. https://doi.org/10.5700/rausp1226

Ritson, M. (2002). Marketing and HE collaborate to harness employer brand power. Marketing, 24.

Roth, P. L., Bobko, P., Van Iddekinge, C. H., \& Thatcher, J. B. (2016). Social media in employee-selection-related decisions: A research agenda for uncharted territory. Journal of Management, 42(1), 269-298. https://doi.org/10.1177/0149206313503018

Roy, K. S. (2008). Identifying the dimensions of attractiveness of an employer brand in the Indian context. South Asian Journal of Management, 15(4), 110-130.

Saini, G. K., Rai, P., \& Chaudhary, M. K. (2014). What do best employer surveys reveal about employer branding and intention to apply? Journal of Brand Management, 21, 95-111. https://doi.org/10.1057/bm.2013.10

Sears, D. (2003). Successful talent strategies: Achieving superior business results through market-focused staffing. New York: Amacom.

Sivertzen, A. M., Nilsen, E., \& Olafsen, H. A. (2013). Employer branding: Employer attractiveness and the use of social media. Journal of Product \& Brand Management, 22(7), 473-483. https://doi.org/10.1108/JPBM-09-2013-0393

Schuler, R. S., Jackson, S. E., \& Tarique, I. (2011). Global talent management and global talent challenges: Strategic opportunities for IHRM. Journal of World Business, 46(4), 506-516. https://doi.org/10.1016/j.jwb.2010.10.011

Slaughter, J. E., Cable, D. M., \& Turban, D. B. (2014). Changing job seekers' image perceptions during recruitment visits: The moderating role of belief confidence. Journal of Applied Psychology, 99(6), 1146-1158. https://doi.org/10.1037/a0037482

Srivastava, P., \& Bhatnagar, J. (2010). Employer brand for talent acquisition: An exploration towards its measurement. Journal of Business Perspective, 14(1/2), 25-34. https://doi.org/ 10.1177/097226291001400103

Urbancova, H., Richter, P., Kucirkova, L., \& Jarkovska, M. (2017). Employer branding in the agricultural sector: Making a company attractive for the potential employees. Agricultural Economics, 63(5), 217-227. https://doi.org/10.17221/338/2015-AGRICECON

Verčič, T. A., \& Ćorić, S. D. (2018). The relationship between reputation, employer branding and corporate social responsibility. Public Relations Review, 44, 444-452. https://doi.org/10.1016/j.pubrev.2018.06.005

Weigelt, K., \& Camerer, C. (1988). Reputation and corporate strategy: a review of recent theory and applications. Strategic Management Journal, 9(5), 443-454. https://doi.org/10.1002/smj.4250090505 